Research Article

\title{
Preparation and Biological Activities of Some Heterocyclic Compounds Derivatives from 2-Aminothiazoles
}

\author{
Faez Abdul-hussein Alrammahi \\ Department of Chemistry, Faculty of Education for Girls, University of Kufa, Al-Najaf, Iraq. \\ Corresponding author. E-mail: faez.alrammahi@uokufa.edu.iq
}

Received: Mar. 12, 2017; Accepted: May 4, 2018; Published: May 8, 2018.

Citation: Faez Abdul-hussein Alrammahi, Preparation and Biological Activities of Some Heterocyclic Compounds Derivatives from 2-Aminothiazoles. Nano Biomed. Eng., 2018, I0(2): I29-140.

DOI: 10.5101/nbe.v10i2.p129-140.

\begin{abstract}
In the current investigation, two series of 2-amino thiazole derivatives were prepared. The first series involved synthesis of (Z)-3-(thiazol-2-ylimino)indolin-2-one (A1) as Schiff base derivatives of 2-amino thiazole and isatin, then synthesis of compounds A5, A6 and A7 as five membered rings (imidazolidins) by using different amino acids, and synthesis of compounds A3 and A4 as seven membered rings (1,3-oxazepine-di-one) by using maleic and phthalic anhydrides respectively. In the second series, 2-amino thiazole was treated with acetyl acetone to form (2E,4E)-N2,N4-di(thiazol-2-yl) pentane-2,4-diimine (A2) as di-Schiff base derivatives, and finally the preparation of imidazolidin (A8) by using $2 \mathrm{~mol}$ of tyrosine and preparation of tetrazole derivative (A9) by using 2 mol of sodium azide. The biological study for the above two series indicated that both gram-negative and grampositive activities were noticed.
\end{abstract}

Keywords: 2-aminothiazoles; Tetrazole; Imidazolodine; Benzoxazepine; Oxazepin; Isatin; Schiff base

\section{Introduction}

Thiazoles are five-membered heterocyclic aromatic compound which was first prepared by A. Hantzsch [1] in 1888. The ability of aminothiazoles to form protontransfer complexes was developed in order to gain structural information enabling a study of the effect of amino group on 2-aminohistamine derivatives [2, 3]. The synthesis of 2-aminothiazoles derivatives has several problems including low yield, harsh reactions, difficult isolation procedures, use of expensive catalysts [4-6] and so on. Thiazole derivatives are significantly important heterocyclic compounds which exhibit a wide range of biological activities such as fungicidal [7], bactericidal [8], cardiovascular [9], antitumor [10], anti-allergic [11], central nervous system stimulate $[12,13]$ and antipyretic [14]. Due to the broad range of their applications, 2-aminothiazoles have been used in the synthesis of polymers $[15,16]$. In this study, some of the heterocyclic compound derivatives from 2-aminothiazoles were prepared and investigated.

Scheme 1 summarized pathway of the preparation of compounds A1-A9.

\section{Experimental}

Physical properties of compounds A1-A9 are listed 


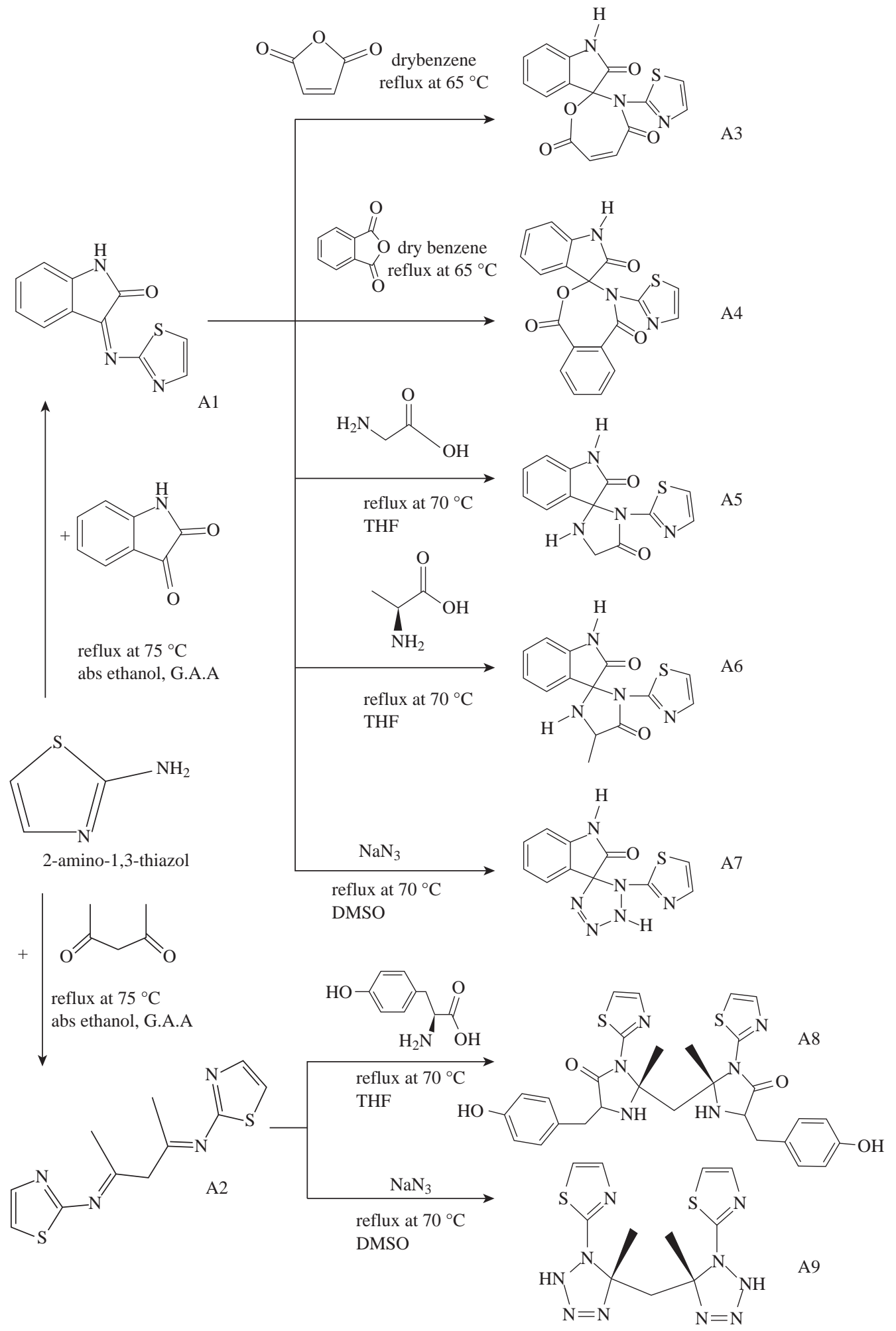

Scheme 1 Synthetic pathway of the preparation of compounds A1-A9.

in Table 1.

\section{Synthesis of (Z)-3-(thiazol-2-ylimino)indolin-2- one (A1)}

Isatin (6 mmol, $0.6 \mathrm{~g})$ was dissolved in $(30 \mathrm{~mL})$ absolute ethanol (abs. EtOH) in a $100 \mathrm{~mL}$ round bottom flask; two drops of glacial acetic acid (GAA) were added and stirred; $0.883 \mathrm{~g}$ of $6 \mathrm{mmol} 2$-aminothiazole was added. The reaction mixture was refluxed for $7 \mathrm{~h}$ at $70-75^{\circ} \mathrm{C}$. Progress of the reaction was monitored by thin layer chromatography (TLC); the resulting product was washed, dried and recrystallized from ethanol.

Fourier-transform infrared spectroscopy (FTIR/ 
Table 1 Physical properties for product compounds

\begin{tabular}{|c|c|c|c|c|c|c|}
\hline Compounds & $\begin{array}{l}\text { Molecular } \\
\text { formula }\end{array}$ & $\begin{array}{l}\text { Molecular weight } \\
\quad(\mathrm{gm} / \mathrm{mol})\end{array}$ & m.p. $\left({ }^{\circ} \mathrm{C}\right)$ & Colors & Ylide (\%) & $\begin{array}{c}\mathrm{R}_{\mathrm{f}} \\
\text { Methanol: } \\
\text { Benzene }=1: 4\end{array}$ \\
\hline A1 & $\mathrm{C}_{11} \mathrm{H}_{7} \mathrm{~N}_{3} \mathrm{OS}$ & 239 & 195 & Red & 78 & 0.62 \\
\hline A2 & $\mathrm{C}_{11} \mathrm{H}_{12} \mathrm{~N}_{4} \mathrm{~S}_{2}$ & 264 & $107-108$ & Dark Brawn & 67 & 0.76 \\
\hline A3 & $\mathrm{C}_{15} \mathrm{H}_{9} \mathrm{~N}_{3} \mathrm{O}_{4} \mathrm{~S}$ & 327 & 175 & Red Brown & 83 & 0.42 \\
\hline A4 & $\mathrm{C}_{19} \mathrm{H}_{11} \mathrm{~N}_{3} \mathrm{O}_{4} \mathrm{~S}$ & 377 & 165 & black Brown & 80 & 0.41 \\
\hline A5 & $\mathrm{C}_{13} \mathrm{H}_{10} \mathrm{~N}_{4} \mathrm{O}_{2} \mathrm{~S}$ & 166 & $177-179$ & Deep Brown & 74 & 0.53 \\
\hline A6 & $\mathrm{C}_{14} \mathrm{H}_{12} \mathrm{~N}_{4} \mathrm{O}_{2} \mathrm{~S}$ & 300 & 144 & Dark Red & 79 & 0.43 \\
\hline A7 & $\mathrm{C}_{11} \mathrm{H}_{8} \mathrm{~N}_{6} \mathrm{OS}$ & 277 & $180-181$ & Brown & 77 & 0.52 \\
\hline A8 & $\mathrm{C}_{29} \mathrm{H}_{30} \mathrm{O}_{4} \mathrm{~N}_{6} \mathrm{~S}_{2}$ & 590 & 165 & Brown & 79 & 0.58 \\
\hline A9 & $\mathrm{C}_{11} \mathrm{H}_{14} \mathrm{~N}_{10} \mathrm{~S}_{2}$ & 350.43 & 174 & Dark Brawn & 65 & 0.44 \\
\hline
\end{tabular}

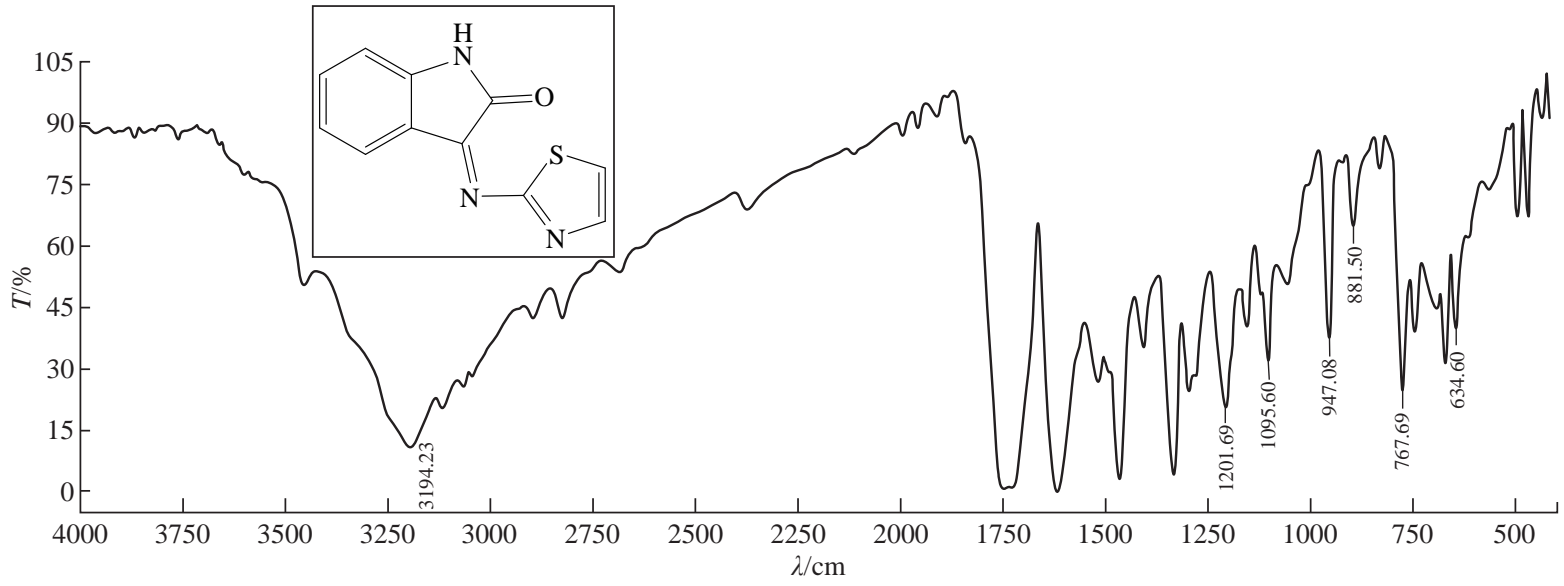

Fig. 1 FTIR spectrum of compound A1.

cm: 1637 (vC=N, imine); 1750 (vC=O, carbonyl of indolone); 1450 and 1500 (vC=C, aromatic and vinyl and $v \mathrm{C}=\mathrm{N}$, thiazole, vib. coupling); $3450(\mathrm{~N}-\mathrm{H}$, of

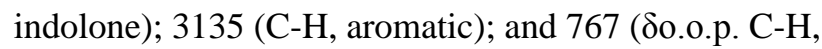
benzene) (Fig. 1; Table 2).

Proton nuclear magnetic resonance $\left({ }^{1} \mathrm{H}-\mathrm{NMR}\right): \mathrm{d} /$ ppm: 7.32-7.951 (s, 4H, phenyl); 7.271 (2H, olifinic of thiazole); and 8,049 (s, H, N-H, indolone) (Fig. 2; Table 3).

Elemental analysis calculated for A1 $\left(\mathrm{C}_{11} \mathrm{H}_{7} \mathrm{~N}_{3} \mathrm{OS}\right)$ : C, 61; H, 3.16; N, 19.5; S, 14.6; Found C, 61.47; H, 3.28; N, 19.7; and S, 15 (Table 4).

\section{Synthesis of (N,N'E,N,N'E)-N,N'-(pentane-2,4- diylidene) bis (thiazol-2-amine) (A2)}

$0.3 \mathrm{~g}$ of $3 \mathrm{mmol}$ acetyl acetone was dissolved in 30 $\mathrm{mL}$ abs. EtOH in a $100 \mathrm{~mL}$ round bottom flask; three drops of GAA were added and stirred; $0.6 \mathrm{~g}$ of $6 \mathrm{mmol}$ 2-aminothiazole was added. The reaction mixture was refluxed for $8 \mathrm{~h}$ at $70{ }^{\circ} \mathrm{C}$. Progress of the reaction was monitored by TLC. The resulting product was washed, dried and recrystllizaed from ethanol.

FTIR/cm: $1608(v \mathrm{C}=\mathrm{N}$, imine); 1589 and 1500 (vC=C, vinyl and $v \mathrm{C}=\mathrm{N}$, thiazole, vib. coupling); 3450 (N-H, of indolone); 3182 (C-H, aromatic); 2972 (CH, methyl); 1442 (C-N, thiazole); and 1041.6 (C-S, thiazole) (Fig. 3; Table 2).

$\mathrm{H}^{1}$-NMR: /ppm: 1.408 (s, 6H, methyl); 6,917-7.271 (2H, olifinic of thiazole); and 2.419 (s, $\mathrm{CH}_{2}$ ) (Fig. 4; Table 3).

Elemental analysis for $\mathrm{A} 1\left(\mathrm{C}_{11} \mathrm{H}_{7} \mathrm{~N}_{3} \mathrm{OS}\right)$ : C, 61; $\mathrm{H}$, 3.16; N, 19.5; S, 14.6; Found C, 61.47; H, 3.28; N, 19.7; and S, 15 (Table 4). 
Table 2 FTIR for product compounds A1-A9

\begin{tabular}{|c|c|c|c|c|c|c|c|}
\hline \multirow[t]{2}{*}{ Compounds } & \multicolumn{7}{|c|}{$\mathrm{FTIR} / \mathrm{cm}$} \\
\hline & \multicolumn{2}{|c|}{$\begin{array}{l}\text { Amide } \\
v(\mathrm{C}=\mathrm{O})\end{array}$} & $\begin{array}{c}\text { Imine } \\
v(C=N)\end{array}$ & $\begin{array}{c}\text { Aromatic } \\
v(C=C)\end{array}$ & $\begin{array}{c}\text { Aromatic } \\
v(\mathrm{C}-\mathrm{H})\end{array}$ & \multicolumn{2}{|c|}{$\begin{array}{l}\text { Aliphatic } \\
\text { v(C-H) }\end{array}$} \\
\hline \multirow[t]{2}{*}{ A1 } & \multicolumn{2}{|c|}{1750} & 1637 & 1450.09 & 3135 & \multicolumn{2}{|c|}{2900} \\
\hline & $\begin{array}{c}\text { Imine } \\
v(C=N)\end{array}$ & $\begin{array}{l}\text { Thiazole } \\
v(C=N)\end{array}$ & $\begin{array}{l}\text { Aliphatic } \\
v(\mathrm{C}-\mathrm{H})\end{array}$ & $\begin{array}{c}\text { Aromatic } \\
v(\mathrm{C}-\mathrm{H})\end{array}$ & $\begin{array}{c}\text { Thiazole } \\
v(\mathrm{C}-\mathrm{N})\end{array}$ & & \\
\hline \multirow[t]{2}{*}{ A2 } & 1608.96 & 1589 & 2972 & 3182 & 1442 & \multicolumn{2}{|c|}{1041} \\
\hline & $\begin{array}{c}\text { Ester } \\
v(\mathrm{C}=\mathrm{O})\end{array}$ & $\begin{array}{l}\text { Amide } \\
v(\mathrm{C}=\mathrm{O})\end{array}$ & $\begin{array}{l}\text { Alkene } \\
v(C=C)\end{array}$ & $\begin{array}{c}\text { Aromatic } \\
v(\mathrm{C}-\mathrm{H})\end{array}$ & $\begin{array}{l}\text { Aliphatic } \\
\text { v(C-H) }\end{array}$ & \multicolumn{2}{|c|}{$\begin{array}{l}\text { Amine } \\
v(\mathrm{NH})\end{array}$} \\
\hline A3 & 1735 & 1680 & 1618,1462 & 3194 & 2985 & \multicolumn{2}{|c|}{3400} \\
\hline \multirow[t]{2}{*}{ A4 } & 1724 & 1651 & 1618 & 3194 & 2995 & \multicolumn{2}{|c|}{3381} \\
\hline & $\begin{array}{l}\text { Ketone } \\
v(C=O)\end{array}$ & $\begin{array}{l}\text { Amine } \\
v(\mathrm{NH})\end{array}$ & $\begin{array}{l}\text { Alkene } \\
v(C=C)\end{array}$ & $\begin{array}{c}\text { Aliphatic } \\
v(\mathrm{C}-\mathrm{H})\end{array}$ & $\begin{array}{c}\text { Aromatic } \\
v(\mathrm{C}-\mathrm{H})\end{array}$ & $\begin{array}{l}\text { Thiazole } \\
v(C=N)\end{array}$ & $\begin{array}{c}\text { Hydroxyl } \\
v(\mathrm{OH})\end{array}$ \\
\hline A5 & 1738,1653 & 3194, 3292 & 1620 & 2956 & 3052 & 1506 & -- \\
\hline A6 & 1725 & 3194, 3300 & 1620 & 2928 & 3050 & 1512 & -- \\
\hline \multirow[t]{2}{*}{ A8 } & 1735.93 & 3300 & 1627 & 2962 & 3120.82 & 1525 & 3415 \\
\hline & $\begin{array}{c}\text { Keton } \\
v(\mathrm{C}=\mathrm{O})\end{array}$ & $\begin{array}{c}\text { Azo } \\
v(\mathrm{~N}=\mathrm{N})\end{array}$ & $\begin{array}{c}\text { Imine } \\
v(C=N)\end{array}$ & $\begin{array}{l}\text { Amine } \\
v(\mathrm{NH})\end{array}$ & & $\begin{array}{c}\text { Aliphatic } \\
v(\mathrm{C}-\mathrm{H})\end{array}$ & \\
\hline A7 & 1745 & 1508.38 & 1629 & 3250,3487 & & 2856 & \\
\hline A9 & -- & 1560 & 1592 & 3363 & & 2956 & \\
\hline
\end{tabular}

Table $3 \mathrm{H}^{1}$-NMR for product compounds A1, A2, A3 and A8

\begin{tabular}{|c|c|c|c|c|c|c|c|c|}
\hline Compounds & $\begin{array}{c}\text { Molecular } \\
\text { formula. }\end{array}$ & OH hydroxyl & $\mathrm{CH}$ aromatic & $\begin{array}{l}\text { CH olivine } \\
\text { of oxazepine }\end{array}$ & $\begin{array}{l}\text { CH olivine } \\
\text { of thiazole }\end{array}$ & $\begin{array}{c}\mathrm{NH} \\
\text { indolone }\end{array}$ & $\mathrm{CH}_{3}$ methyl & $\begin{array}{c}\mathrm{CH}_{2}^{+} \\
\mathrm{CH}_{2} \text {-phenyl }\end{array}$ \\
\hline A1 & $\mathrm{C}_{11} \mathrm{H}_{7} \mathrm{~N}_{3} \mathrm{OS}$ & -- & 7.32-7.951 & -- & 7.271 & 8.049 & -- & -- \\
\hline A2 & $\mathrm{C}_{11} \mathrm{H}_{12} \mathrm{~N}_{4} \mathrm{~S}_{2}$ & -- & -- & -- & $6,917-7.271$ & -- & 1.408 & 2.419 \\
\hline A3 & $\mathrm{C}_{15} \mathrm{H}_{9} \mathrm{~N}_{3} \mathrm{O}_{4} \mathrm{~S}$ & -- & $7.584-7.484$ & $7.009-6.577$ & $6.390-6.244$ & 8.094 & -- & -- \\
\hline A8 & $\mathrm{C}_{29} \mathrm{H}_{30} \mathrm{O}_{4} \mathrm{~N}_{6} \mathrm{~S}_{2}$ & 9.014 & 7.772-7.416 & -- & 7.929 & $7.947-7.839$ & 2.503 & 3.329-7.016 \\
\hline
\end{tabular}

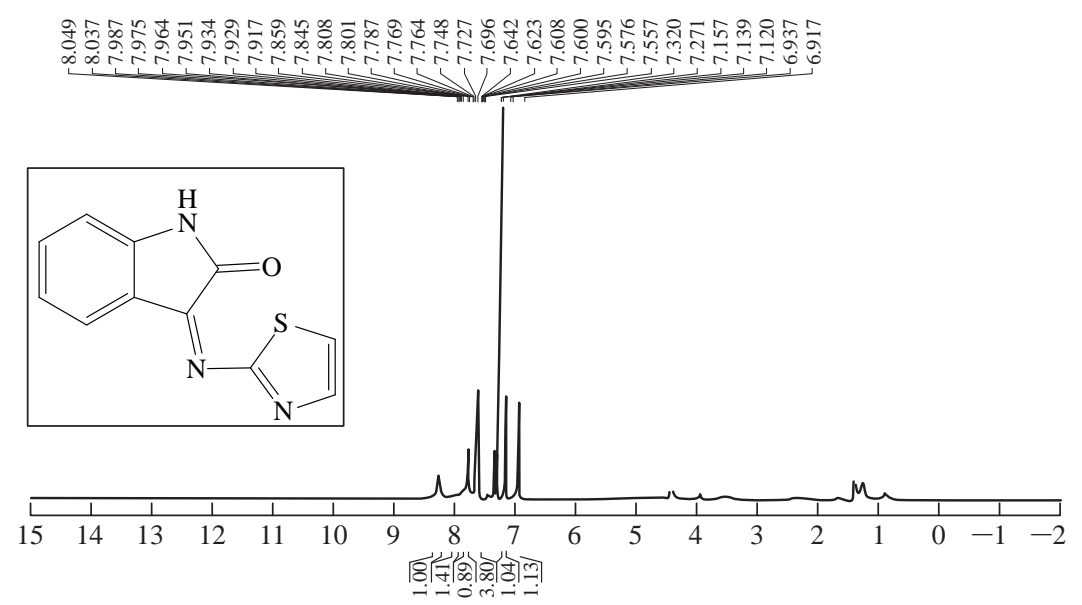

Fig. $2{ }^{1} \mathrm{H}-\mathrm{NMR}$ spectrum of compound A1. 


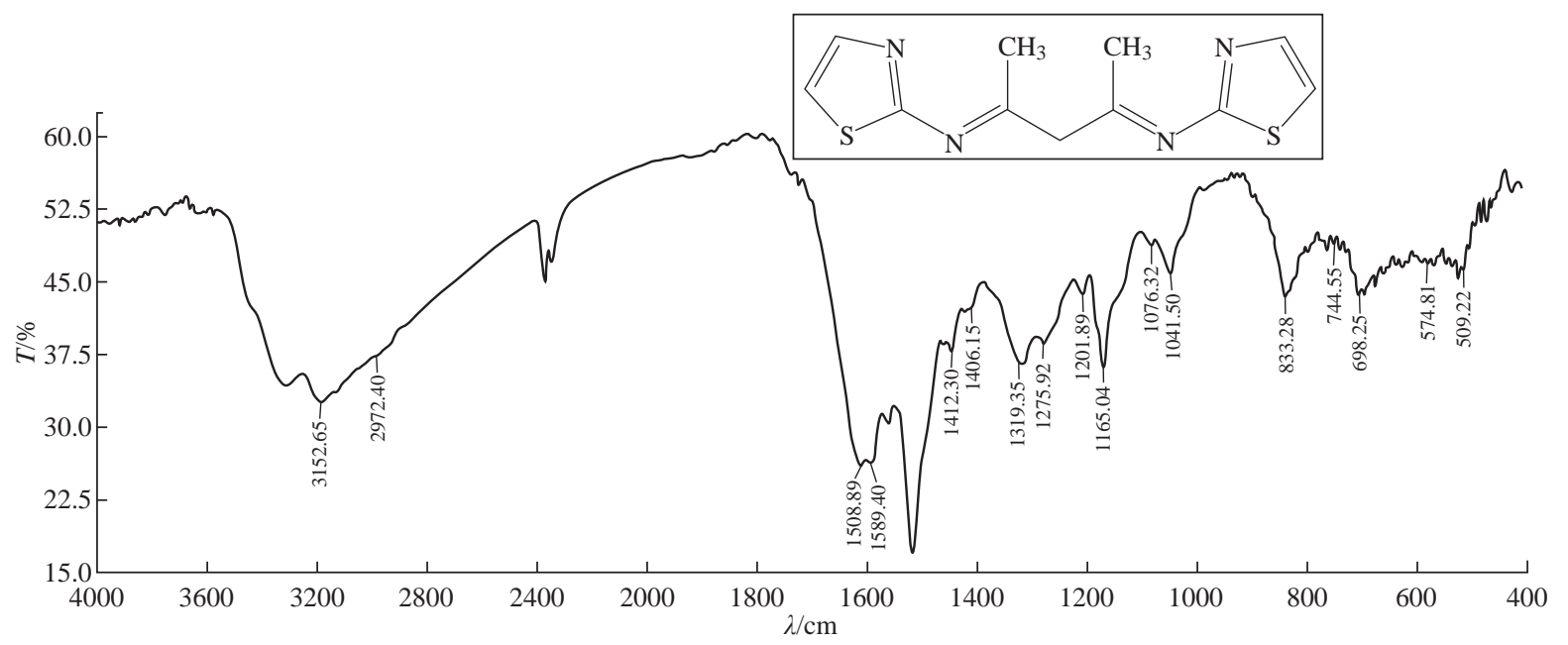

Fig. 3 FTIR spectrum of compound A2.

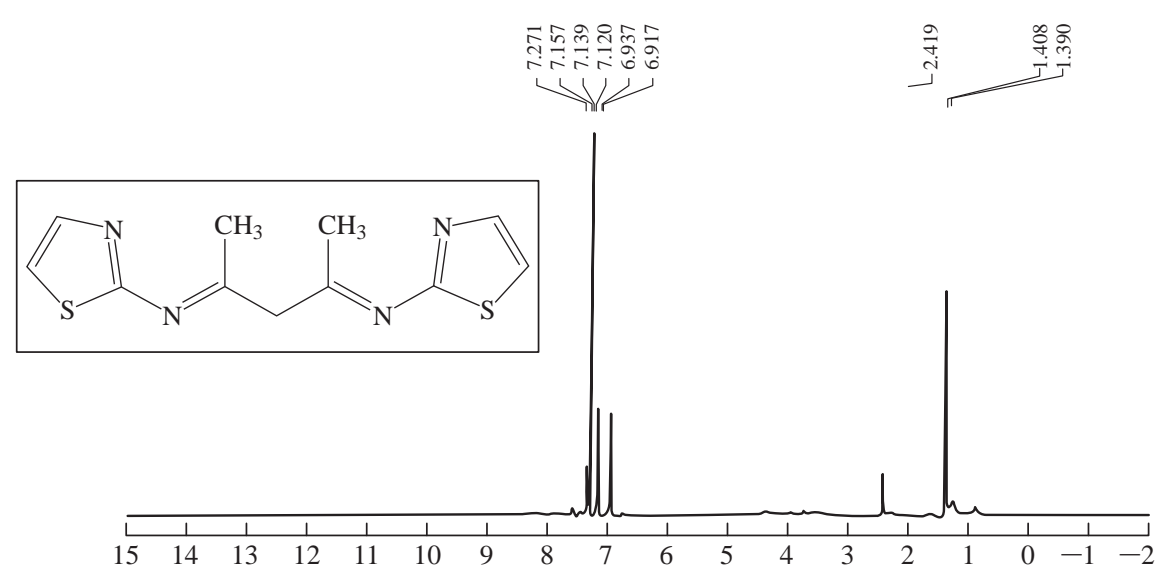

Fig. $4{ }^{1} \mathrm{H}$-NMR spectrum of compound A2.

Table 4 Elemental analysis for product compounds A1, A3, A4, A6 and A8

\begin{tabular}{|c|c|c|c|c|c|c|c|}
\hline Compounds & Molecular formula & Calculated/Observed & $\mathrm{C} \%$ & $\mathrm{H} \%$ & $\mathrm{~N} \%$ & S\% & $\mathrm{O} \%$ \\
\hline \multirow{2}{*}{ A1 } & \multirow{2}{*}{$\mathrm{C}_{11} \mathrm{H}_{7} \mathrm{~N}_{3} \mathrm{OS}$} & Cal. & 58.22 & 3.16 & 19.00 & 14.40 & 6.99 \\
\hline & & Obs. & 57.47 & 3.28 & 18.57 & 14.00 & -- \\
\hline \multirow{2}{*}{ A3 } & \multirow{2}{*}{$\mathrm{C}_{15} \mathrm{H}_{9} \mathrm{~N}_{3} \mathrm{O}_{4} \mathrm{~S}$} & Cal. & 54.53 & 2.50 & 12.24 & 9.20 & 19.55 \\
\hline & & Obs. & 55.02 & 2.72 & 12.80 & 9.71 & -- \\
\hline \multirow{2}{*}{ A4 } & \multirow{2}{*}{$\mathrm{C}_{19} \mathrm{H}_{11} \mathrm{~N}_{3} \mathrm{O}_{4} \mathrm{~S}$} & Cal. & 60.00 & 2.86 & 10.98 & 8.35 & 16.96 \\
\hline & & Obs. & 60.47 & 2.91 & 11.14 & 8.48 & -- \\
\hline \multirow{2}{*}{ A6 } & \multirow{2}{*}{$\mathrm{C}_{14} \mathrm{H}_{12} \mathrm{~N}_{4} \mathrm{O}_{2} \mathrm{~S}$} & Calc. & 55.89 & 3.40 & 18.21 & 10.18 & 10.66 \\
\hline & & Obs. & 56.10 & 3.67 & 18.65 & 10.7 & -- \\
\hline \multirow{2}{*}{ A8 } & \multirow{2}{*}{$\mathrm{C}_{29} \mathrm{H}_{30} \mathrm{O}_{4} \mathrm{~N}_{6} \mathrm{~S}_{2}$} & Cal. & 61.09 & 4.91 & 14.84 & 11.33 & 10.83 \\
\hline & & Obs. & 61.45 & 5.03 & 15.17 & 11.52 & -- \\
\hline
\end{tabular}

Synthesis of 3'-(thiazol-2-yl)-3'Hspiro[indoline-3,2'-[1,3]oxazepine]-2,4',7'trione (A3)

A mixture ( $6 \mathrm{mmol}, 0.128 \mathrm{~g}$ ) of compound A1 and $0.059 \mathrm{~g}$ of $6 \mathrm{mmol}$ maleic anhydride were refluxed in $30 \mathrm{~mL}$ benzene, at $60^{\circ} \mathrm{C}$ for about $20 \mathrm{~h}$, and then recrystllizaed from ethanol.
FTIR/cm: 1680 (vC=O, amide); 1735 (vC=O, carbonyl of indolone and ester); 1618 and $1462(\boldsymbol{v C}=\mathrm{C}$, aromatic and vinyl, vib. coupling); $3400(\mathrm{~N}-\mathrm{H}$, of indolone); 3192 (C-H, aromatic); and 750 (סo.o.p. C-H, benzene) (Fig. 5; Table 2).

$\mathrm{H}^{1}$-NMR: d/ppm: 7.584-7.484 (s, 4H, phenyl); 7.009-6.577 (2H, olivinic of oxazepine); $6.390(2 \mathrm{H}$, 
olivinic of thiazole); and 8,094 (s, H, N-H, indolone) (Fig. 6; Table 3).

Elemental analysis for $\mathrm{A} 3\left(\mathrm{C}_{15} \mathrm{H}_{9} \mathrm{~N}_{3} \mathrm{O}_{4} \mathrm{~S}\right)$ : $\mathrm{C}, 54.5$; H, 2.5; N, 12.24; S, 14.6; Found C, 55.02; H, 2.72; N, 12.80; and S, 9.71 (Table 4).

\section{Synthesis of 4-(thiazol-2-yl)-1H-spiro[benzo[e] $[1,3]$ oxazepine-3,3'-indoline]-1,2',5(4H)-trione (A4)}

A mixture ( $6 \mathrm{mmol}, 0.128 \mathrm{~g}$ ) of compound A1 and $0.089 \mathrm{~g}$ of $6 \mathrm{mmol}$ phthalic anhydride were refluxed in $30 \mathrm{~mL}$ benzene, at 75 for about $24 \mathrm{~h}$, and then recrystllizaed from ethanol.

FTIR/cm: 1727 (vC=O, amide); 1651 (vC=O, carbonyl of indolone and ester); 1618.8 (vC=C, aromatic and vinyl, vib. coupling); $3381(\mathrm{~N}-\mathrm{H}$, of indolone); 3194 (C-H, aromatic); and 669 (סo.o.p. C-H, benzene) (Fig. 7; Table 2).

Elemental analysis for $\mathrm{A} 4\left(\mathrm{C}_{19} \mathrm{H}_{11} \mathrm{~N}_{3} \mathrm{O}_{4} \mathrm{~S}\right)$ : C, 60.00 ; H, 2.86; N, 10.98; S, 8.35; Found C, 60.47; H, 2.91; N,
11.14; and S, 8.48 (Table 4).

\section{Synthesis of 1-(thiazol-2-yl)spiro [imidazolidine-2,3'-indoline]-2',5-dione (A5)}

A mixture $(0.47 \mathrm{mmol}, 0.085 \mathrm{~g})$ of compound A1 and $0.03 \mathrm{~g}$ of $0.47 \mathrm{mmol}$ glycine (an amino acid) were refluxed in $30 \mathrm{~mL}$ tetrahydrofuran (THF), at $70{ }^{\circ} \mathrm{C}$ for about $24 \mathrm{~h}$, and then recrystallized from ethanol.

FTIR/cm: 1738 (vC=O, amide); $1506(\boldsymbol{v C}=\mathrm{N}$, carbonyl); 1620 (vC=C, aromatic and vinyl, vib. coupling); 3292 and 3194 (2N-H, of indolone and imidazolodine); 3052 (C-H, aromatic); 2956 (C-H, aliphatic); and 656 (סo.o.p. C-H, benzene) (Fig. 8; Table 2).

\section{Synthesis of 4-methyl-1-(thiazol-2-yl) spiro[imidazolidine-2,3'-indoline]-2',5-dione (A6)}

A mixture ( $6 \mathrm{mmol}, 0.128 \mathrm{~g})$ of compound A1 and $0.089 \mathrm{~g}$ of $6 \mathrm{mmol}$ alanine (an amino acid) were refluxed in $30 \mathrm{~mL} \mathrm{THF}$, at $70{ }^{\circ} \mathrm{C}$ for about $24 \mathrm{~h}$, and

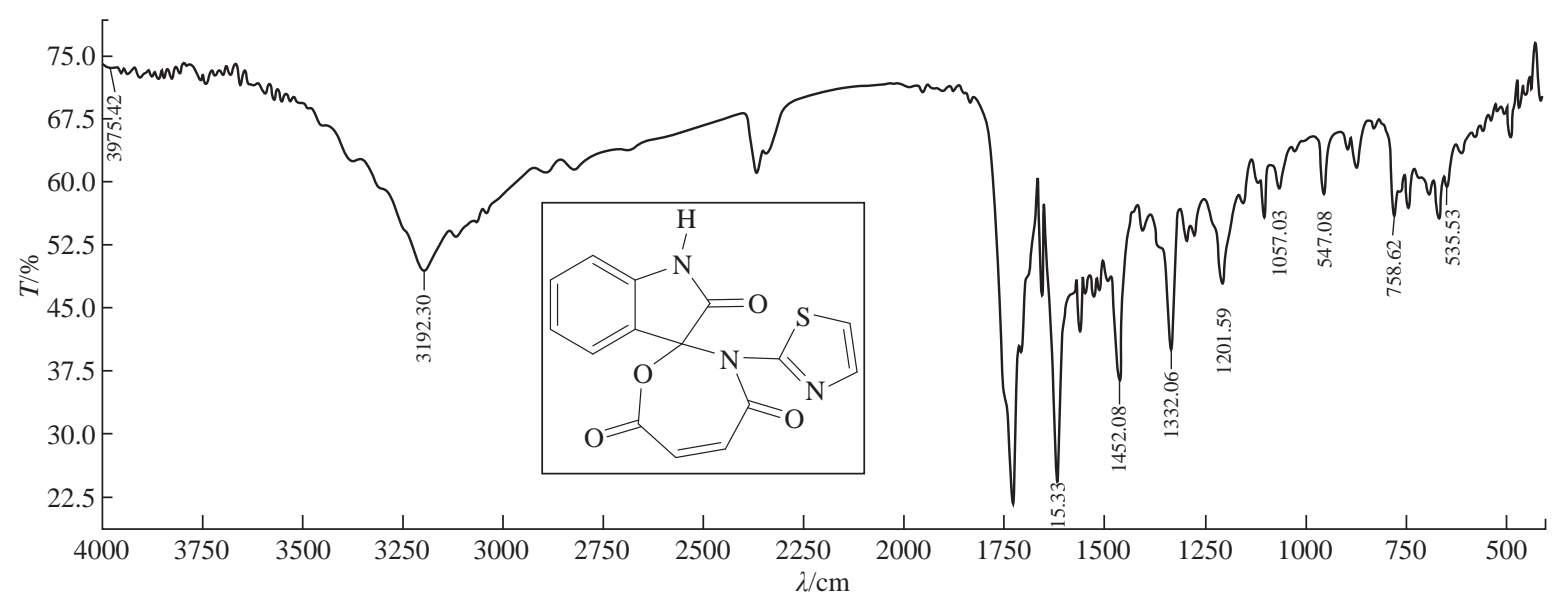

Fig. 5 FTIR spectrum of compound A3.

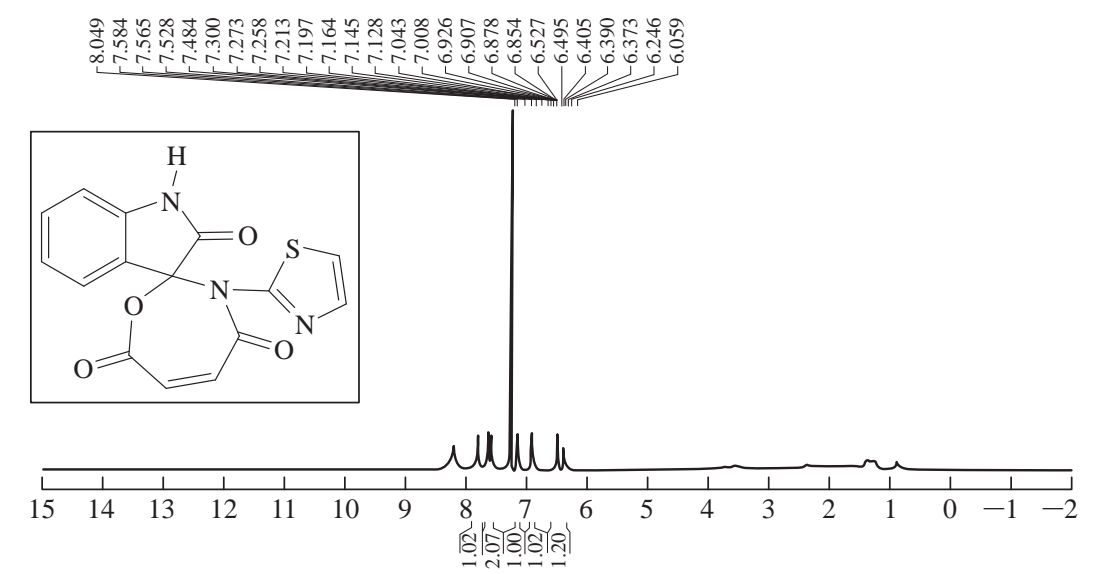

Fig. $6{ }^{1} \mathrm{H}-\mathrm{NMR}$ spectrum of compound A3. 


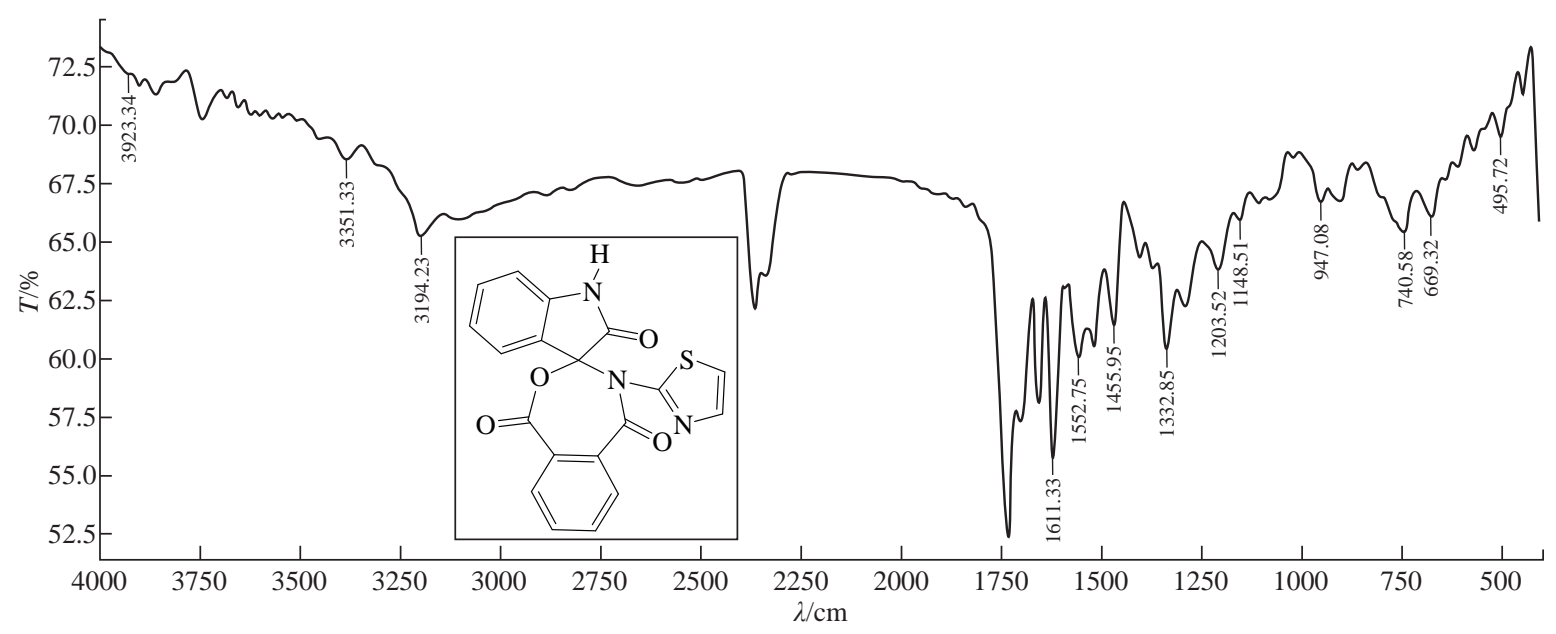

Fig. 7 FTIR Spectrum of compound A4.

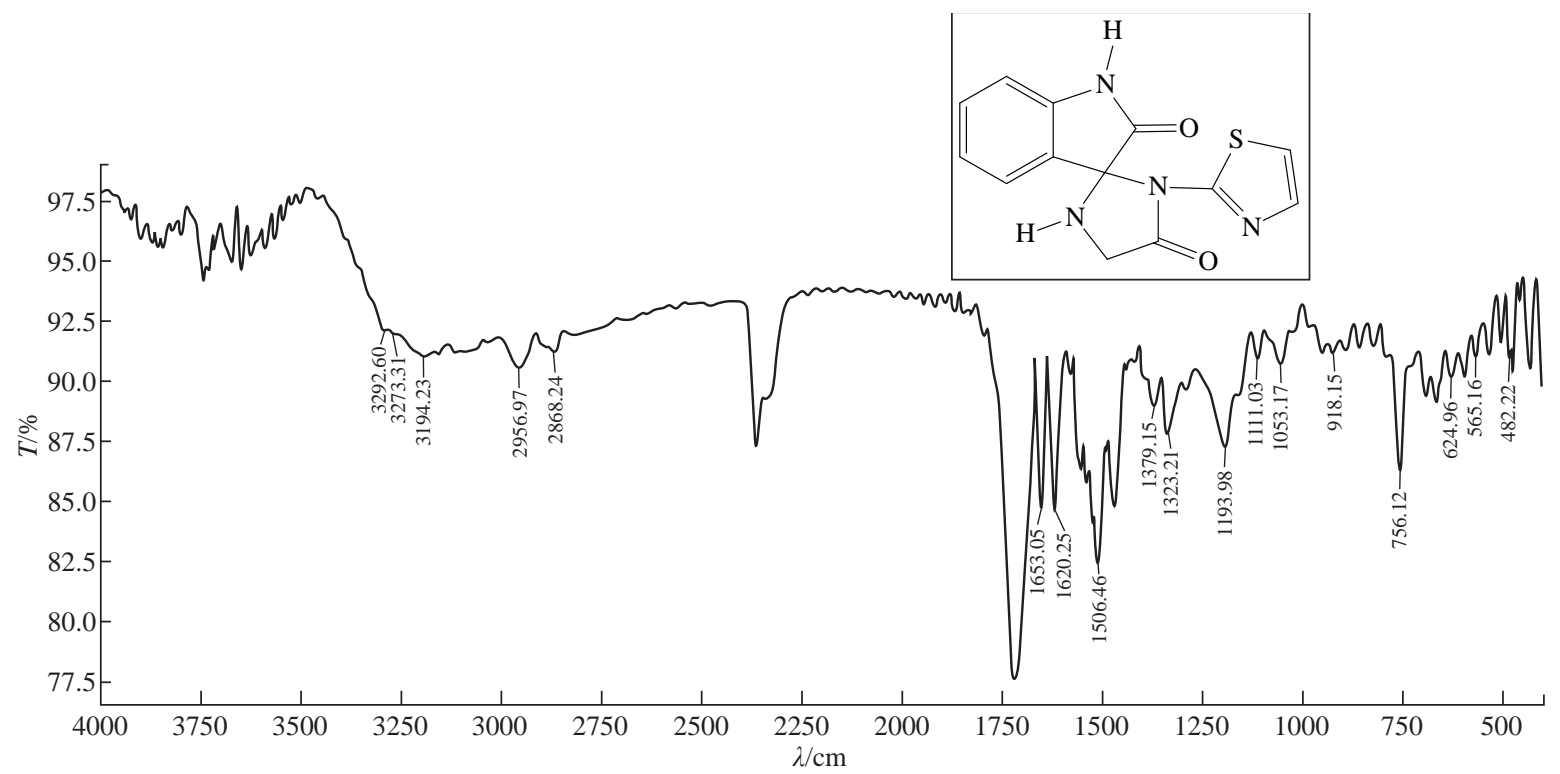

Fig. 8 FTIR spectrum of compound A5.

then recrystallized from ethanol.

FTIR/cm: 1725 (vC=O); 1651 (vC=O, carbonyl of amide); 1620 (vC=C, aromatic and vinyl); 3300 and 3194 (2N-H, of indolone and imidazolodine); 1512 $(v \mathrm{C}=\mathrm{N}$, of thiazole); 3050 (C-H, aromatic); 2928 (C-

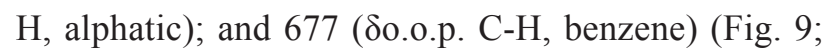
Table 2).

Elemental analysis for A6 $\left(\mathrm{C}_{14} \mathrm{H}_{12} \mathrm{~N}_{4} \mathrm{O}_{2} \mathrm{~S}\right)$ : C, 60.00; H, 2.86; N, 10.98; S, 8.35; Found C, 60.47; H, 2.91; N, 11.14; and $\mathrm{S}, 8.48$.

\section{Synthesis of 1'-(thiazol-2-yl)-1',2'-dihydrospiro [indoline-3,5'-tetrazol]-2-one (A7)}

A mixture (4.7 mmol, $0.1 \mathrm{~g}$ ) of compound A1 and $0.031 \mathrm{~g}$ of $4.7 \mathrm{mmol}$ sodium azide were refluxed in $20 \mathrm{~mL}$ THF, at $70{ }^{\circ} \mathrm{C}$ for about $12 \mathrm{~h}$, and then recrystallized from ethanol.
FTIR/cm: 3487 and 3250 (2N-H, of tetrazole); 2856 (C-H, aliphatic); 1622 (vC=C, of vinyl in thiazole); $1629(\mathrm{vC}=\mathrm{N}$, of thiazole); 1508 ( $\mathrm{NN}=\mathrm{N}$, of tetrazole);

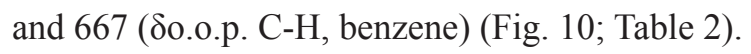

Synthesis of (2S,2'R)-2,2'-methylenebis(5(4-hydroxybenzyl)-2-methyl-3-(thiazol-2-yl) imidazolidin-4-one) (A8)

A mixture (1.5 mmol, $0.396 \mathrm{~g}$ ) of compound A2 and $0.543 \mathrm{~g}$ of $3 \mathrm{mmol}$ tyrosine (an amino acid) were refluxed in $30 \mathrm{~mL} \mathrm{THF}$, at $70{ }^{\circ} \mathrm{C}$ for about $24 \mathrm{~h}$, and then recrystallized from ethanol.

FTIR/cm: $1608(v \mathrm{C}=\mathrm{N}$, imine); 1589 and 1500 (vC=C, vinyl and $v \mathrm{C}=\mathrm{N}$, thiazole, vib. coupling); 3450 (N-H, indolone); 3182 (C-H, aromatic); 2972 (C-H, methyl); 1442 (C-N thiazole); and 1041.6 (C-S thiazole) (Fig. 11; Table 2). 


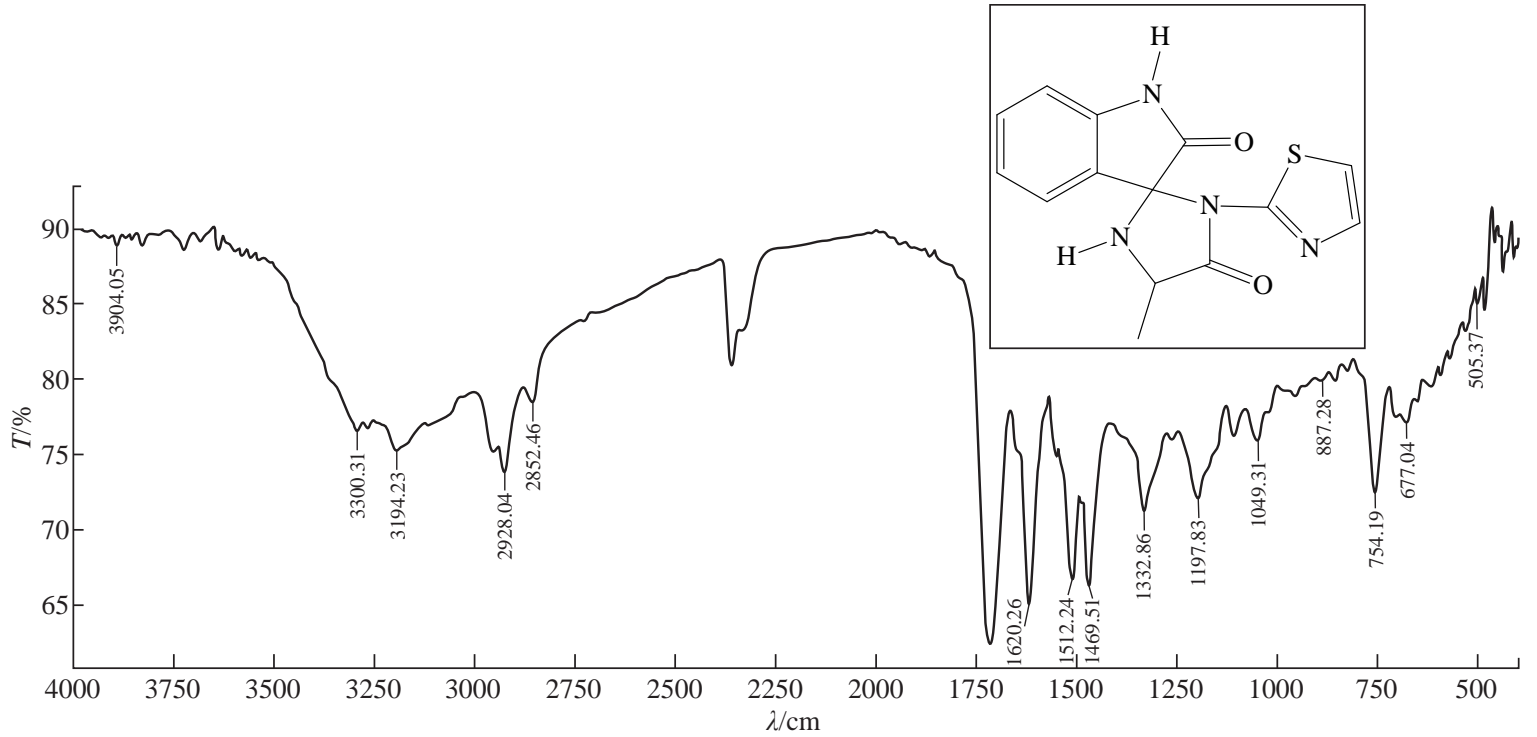

Fig. 9 FTIR spectrum of compound A6.

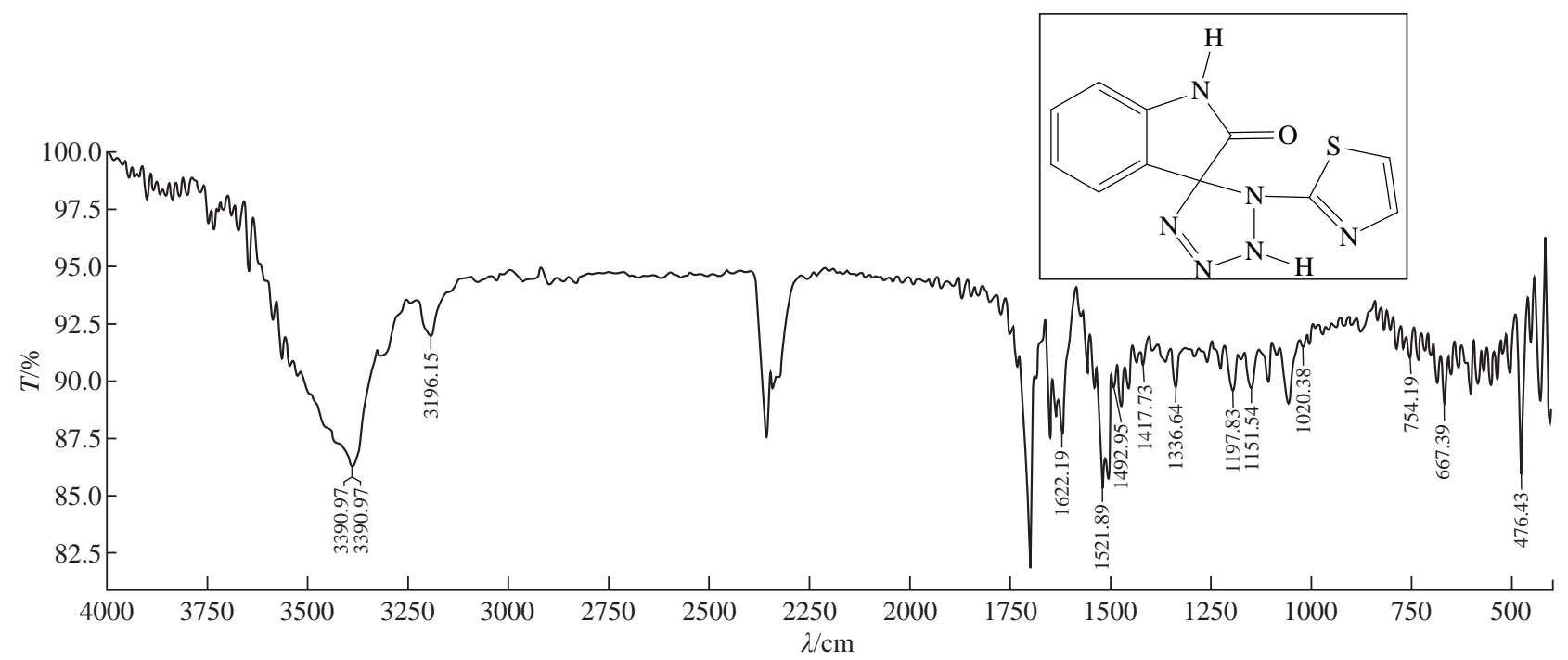

Fig. 10 FTIR spectrum of compound A7.

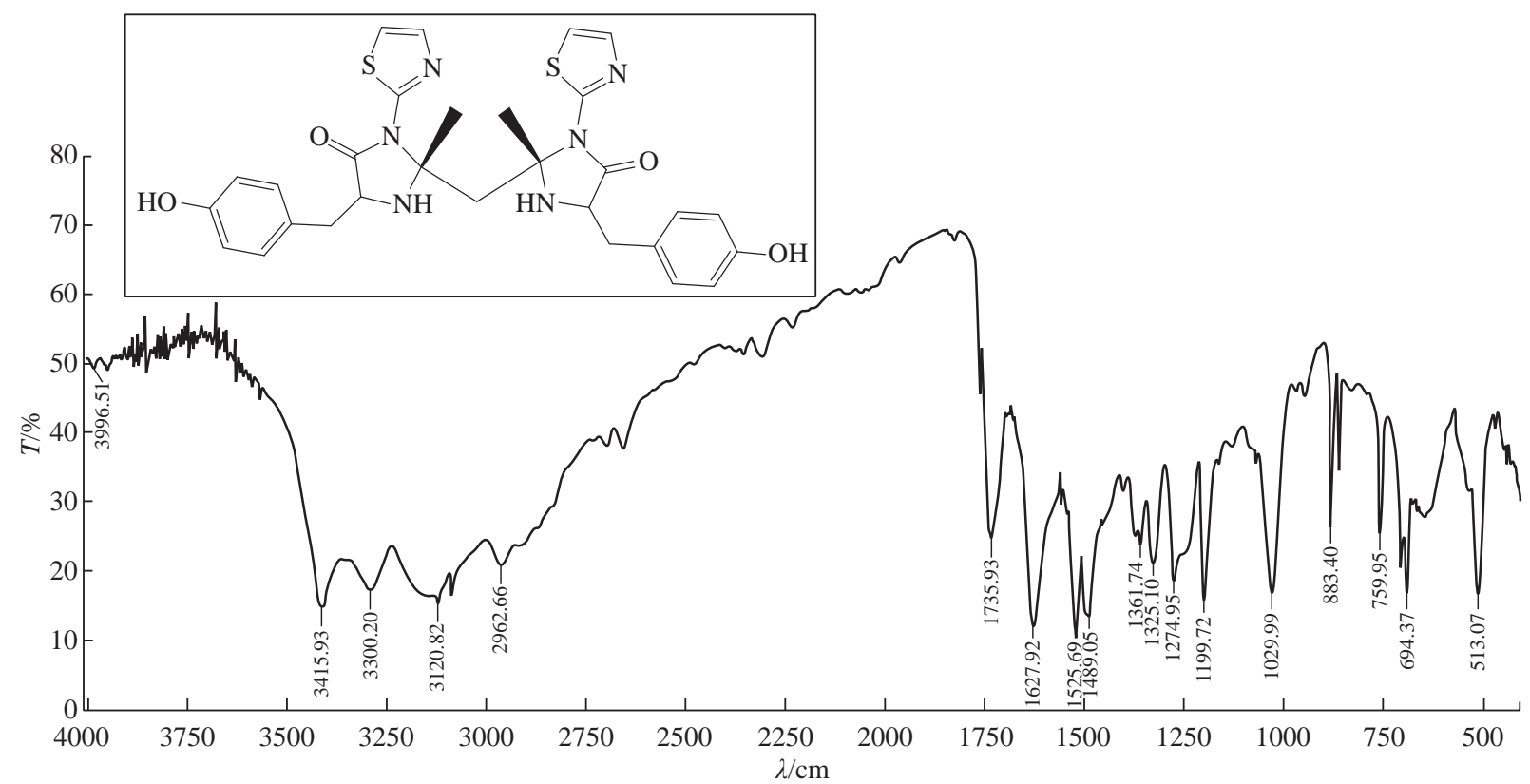

Fig. 11 FTIR spectrum of compound A8. 
$\mathrm{H}^{1}$-NMR: d/ppm): 1.408 (s, 6H, methyl); 6,917$7.271\left(2 \mathrm{H}\right.$, olifinic of thiazole); and $2.419\left(\mathrm{~s}, \mathrm{CH}_{2}\right)$ (Fig. 12; Table 3).

Elemental analysis for $\mathrm{A} 8\left(\mathrm{C}_{29} \mathrm{H}_{30} \mathrm{O}_{4} \mathrm{~N}_{6} \mathrm{~S}_{2}\right)$ : C, 61.09; H, 4.91; N, 14.84; S, 11.33; Found C, 61.45; H, 5.03; N, 15.17; and S, 11.52 (Table 4).

Synthesis of ((R)-5-methyl-1-(thiazol-2-yl)2,5-dihydro-1H-tetrazol-5-yl)((S)-5-methyl1-(thiazol-2-yl)-2,5-dihydro-1H-tetrazol-5-yl) methane (A9)

A mixture $(1.0 \mathrm{mmol}, 0.264 \mathrm{~g})$ of compound A2 and $0.13 \mathrm{~g}$ of $2.0 \mathrm{mmol}$ sodium azide were refluxed in $30 \mathrm{~mL}$ dimethyl sulfoxide (DMSO), at $70{ }^{\circ} \mathrm{C}$ for about $14 \mathrm{~h}$, and then recrystallized from ethanol.

FTIR/cm: 3400 and 3363 (N-H, of tetrazole); 2856 (C-H, aliphatic); 1629 (vC=N, of thiazole); and 1592 (vC=N, thiazole) (Fig. 13; Table 2).

\section{Results and Discussion Biological activity}

According to the World Health Organization (WHO), microorganisms are still the main obstacle to the treatment of infectious diseases, and the preparation of therapeutic agents as a highly selective antimicrobials within the limits of specific concentrations [17, 18]. Five types of pathogenic bacteria were used in the current study, two of them were gram-negative and the other three were gram-positive. The sensitivity was calculated using $1000 \mathrm{ppm}$ degree drilling method, and the employed solvent was DMF [19, 20]. The composition of bacterial cell walls in the gram-negative bacteria presented lower thickness and higher lipophilicity as compared with those of the gram-positive bacteria, thus facilitating the passage of compounds which could be dissolved into the fatty compounds and transferred into the cell. These

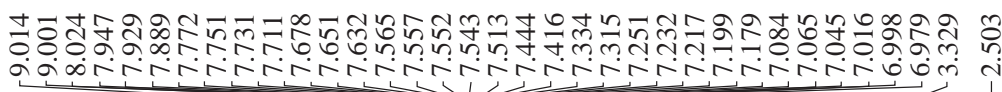

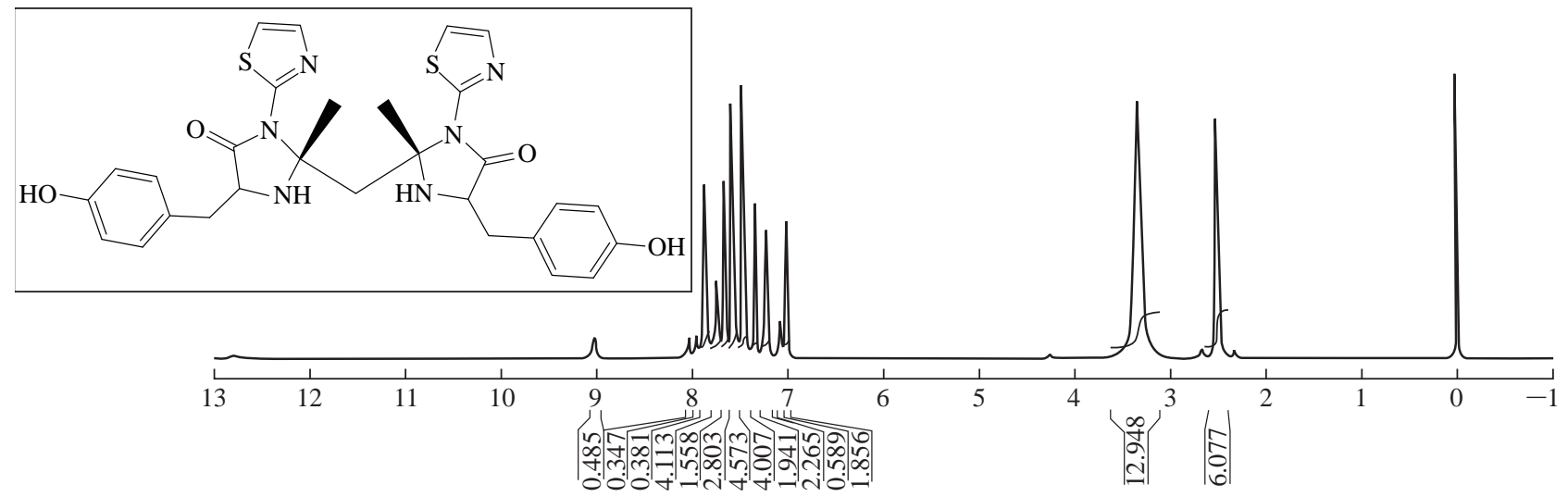

Fig. $12{ }^{1} \mathrm{H}-\mathrm{NMR}$ spectrum of compound A8.

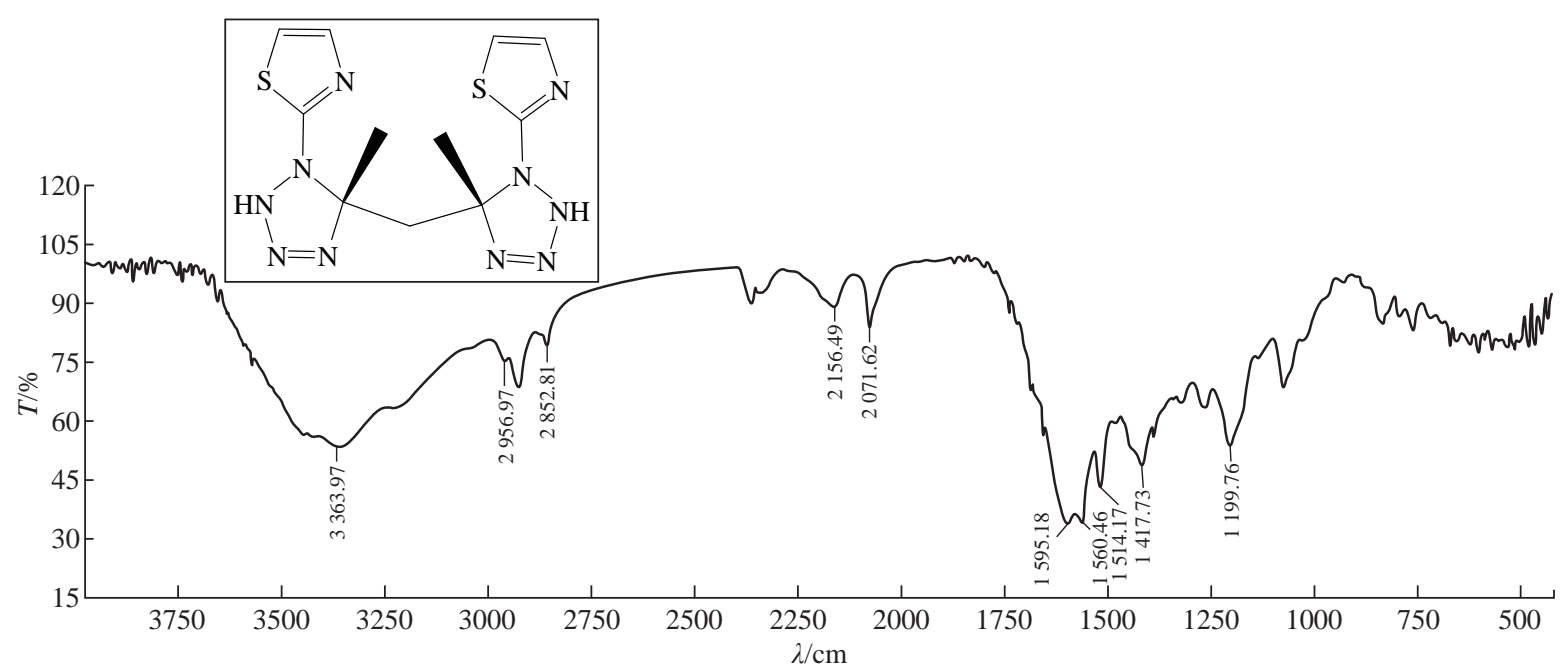

Fig. 13 FTIR spectrum of compound A9. 
compounds inhibited the capture. The bacterial growth through the hardiness of the active sites depended on the Overton concept, the phenomenon of plasmolysis, i.e. a retraction of the protoplasm from the cellulose wall of plant cells exposed to impermeable external solutes. (Overton's system explored the relationship between the chemical constitution of solutes, mainly organic, and their plasmolytic effects, with reference to the properties of the putative osmotic barrier) [21-24]. These sites for respiration and protein synthesis inhibit the formation of hydrogen bonds of some interfaceactive center. Certain cell components or enzymes cause them to stop and change the natural states of cell, leading ultimately to cell death [25]. Table 4 shows the results of biological activity data and the inhibition range in millimeters. Fig. 14 illustrates bacteria wall
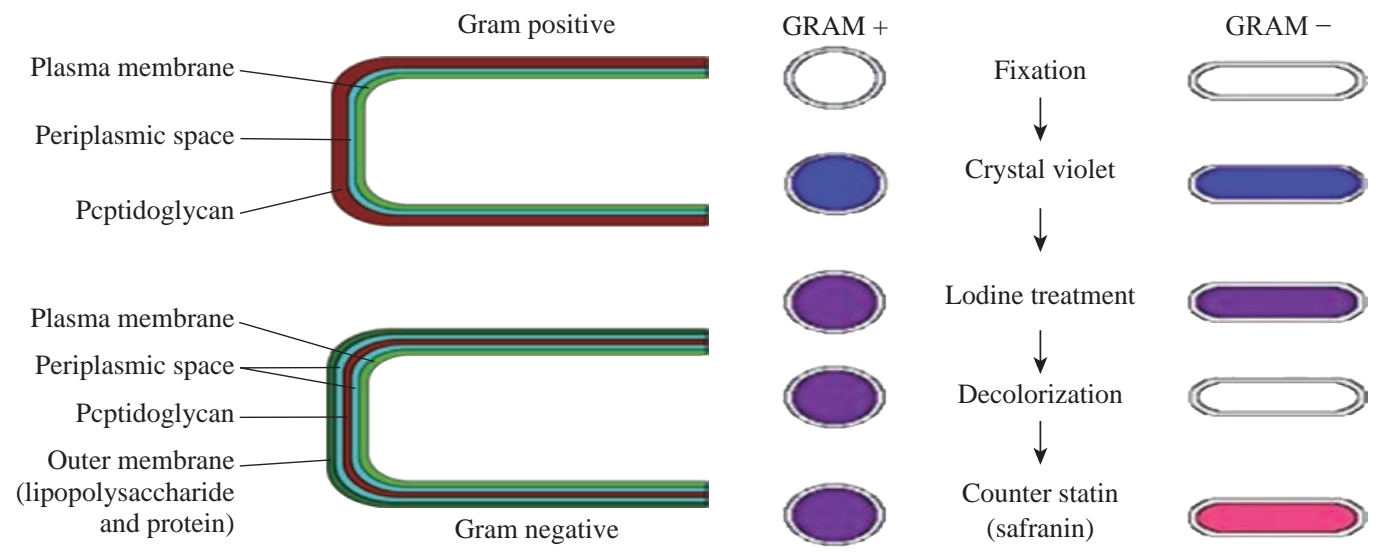

Fig. 14 Bacteria wall and the method of using a gram dyes to differentiate between gram-positive and gram-negative bacteria.

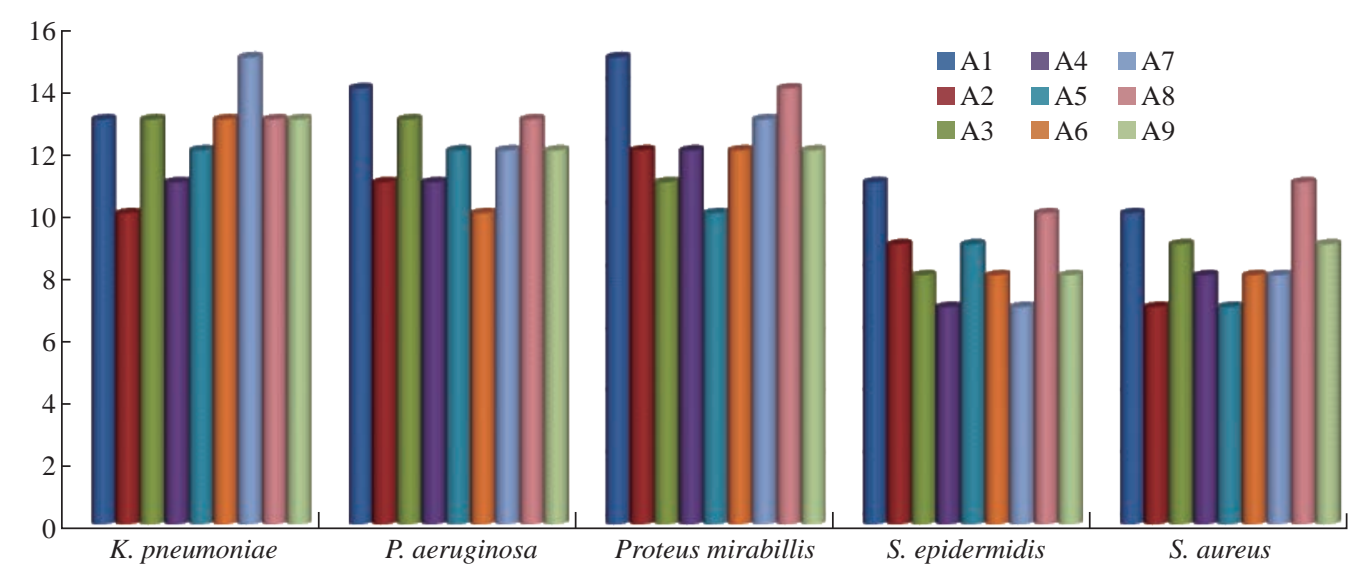

Fig. 15 Statistical representation for antibacterial activity of compounds A1-A9.

Table 5 Biological activity data (zone of inhibition in $\mathrm{mm}$ ) of the compounds A1-A9

\begin{tabular}{|c|c|c|c|c|c|}
\hline \multirow{3}{*}{ Compounds } & \multicolumn{5}{|c|}{ Bacteria } \\
\hline & \multicolumn{3}{|c|}{ Gram-negative } & \multicolumn{2}{|c|}{ Gram-positive } \\
\hline & K. pneumoniae & P. aeruginosa & P. mirabillis & S. epidermidis & S. aureus \\
\hline $\mathrm{A} 1$ & 13 & 14 & 15 & 11 & 10 \\
\hline A2 & 10 & 11 & 12 & 9 & 7 \\
\hline A3 & 13 & 13 & 11 & 8 & 9 \\
\hline A4 & 11 & 11 & 12 & 7 & 8 \\
\hline A5 & 12 & 12 & 10 & 9 & 7 \\
\hline A6 & 13 & 10 & 12 & 8 & 8 \\
\hline A7 & 15 & 12 & 13 & 7 & 8 \\
\hline A 8 & 13 & 13 & 14 & 10 & 11 \\
\hline A9 & 13 & 12 & 12 & 8 & 9 \\
\hline
\end{tabular}


and the method of using a gram dye to differentiate between gram-positive and gram-negative bacteria. Statistical representation for antibacterial activity of compounds A1-A9 is shown in Fig. 15 and Table 5.

\section{Conclusions}

Two series of 2-amino thiazole derivatives were prepared and characterized in this study. FTIR spectroscopy and NMR technique confirmed the formation of these derivatives. Five types of pathogenic bacteria were used, two of them were gram-negative and the other three were gram-positive. A significant biological activity was observed for the above compounds.

\section{Conflict of Interests}

The authors declare that no competing interest exists.

\section{References}

[1] M. Sheikhi, New derivatives of (E,E)-azomethines: Design, quantum chemical modeling, spectroscopic (FT-IR, UV/Vis, polarization) studies, synthesis and their applications: Experimental and theoretical investigations. Journal of Molecular Structure, 2018, 1152: 368-385.

[2] H. Chen, Degradation of azo dye Orange II under dark ambient conditions by calcium strontium copper perovskite. Applied Catalysis B: Environmental, 2018, 221: 691-700.

[3] G. Agnieszka, Synthesis, structure, DNA binding and anticancer activity of mixed ligand ruthenium (II) complex. Journal of Molecular Structure, 2018, 1155: 288-296.

[4] S. Shubha, S. Biju, and V. Sadasivan, Synthesis, structure characterization and biological studies on a new aromatic hydrazone, 5-(2-(1,5-dimethyl-3-oxo-2phenyl-2,3-dihydro-1H-pyrazol-4-yl) hydrazono)-2,2dimethyl-1,3-dioxane-4,6-dione, and its transition metal complexes. Journal of Molecular Structure, 2018, 1156: 201-209.

[5] T. Heraert, Metabolic studies on histidine, histamine, and related imidazoles. Pharmacological reviews, 1954, 6: 299-343.

[6] R. Kenchappa, Y. Bodke, Antifungal and anthelmintic activity of novel benzofuran derivatives containing thiazolo benzimidazole nucleus: an in vitro evaluation. Journal of Chemical Biology, 2017, 10(1): 1123.

[7] M.V. Papadopoulou, W.D. Bloomer, and H.S. Rosenzweig, The antitubercular activity of various nitro (triazole/imidazole)-based compounds. Bioorganic \& Medicinal Chemistry, 2017, 25(21): 6039-6048.

[8] R.T. Iminov, TA.V. verdokhlebov, A.A. Tolmachev, et al.,
Simple and convenient synthesis of 2, 3, 4, 5-tetrahydro-1, 5-dioxopyrrolo [1, 2-a] quinazoline-3a $(1 \mathrm{H})$-carboxylic acids in multi-gram scale. Heterocycles, 2008, 75(7): 1673-1680.

[9] N. Liu, D. Ding, L. Wang, et al., Two novel Mg (II)-based and Zn (II)-based complexes: inhibiting growth of human liver cancer cells. Brazilian Journal of Medical and Biological Research, 2018, 51(2): 12-19.

[10] K. Karrouchi, S. Radi, Y. Ramli, et al., Y., Synthesis and Pharmacological Activities of Pyrazole Derivatives: A Review. Molecules, 2018, 23(1): 134-142.

[11] P. Palanisamy, S.J. Jenniefer, and P.T. Muthiah, Synthesis, characterization, antimicrobial, anticancer, and antituberculosis activity of some new pyrazole, isoxazole, pyrimidine and benzodiazepine derivatives containing thiochromeno and benzothiepino moieties. RSC Advances, 2013, 3(42): 19300-19310.

[12] M.A. Metwally, Y.A. Suleiman, M.A. Gouda, et al., Synthesis, antitumor and antioxidant evaluation of some new antipyrine based azo dyes incorporating pyrazolone moiety. Int. J. Mod. Org. Chem., 2012, 1(3): 213-225.

[13] R.E. Hoover, R.A. Day, Preparation of some imidazole derivatives of 1, 4-naphthoquinone. Journal of the American Chemical Society, 1954, 76(16): 4148-4152.

[14] S. Shozo, F. Masamichi, and N. Ryozo, Syntheses of azo dyes containing 4,5-diphenylimidazole and their evaluation as analytical reagents. Analytica Chimica Acta, 1976, 81: 131-141.

[15] H. Huheey, E.A. Keiter, and R.L. Keiter, Inorganic chemistry: principles of structure and reactivity, 4th ed. Harper Collin College Publishers, 1993: 122-124.

[16] N. Raman, J.D. Raja, Synthesis, structural, characterization and antibacterial studies of some bio sensitive mixed ligand copper (II) complexes. Indian $J$. Chem., 2007, 46A: 1611-1614.

[17] A.S. Al-Rammahi, A.H. Al-khafagy, Synthesis and characterization of oxazepen and imidazolin derivatives from 2-amino-5-mercapto 1,3,4-thiadiazol and studing of their biological activity. Word J. pharm. Res., 2015, 4(2): 1668-1680.

[18] A.H. Al-Khafagy, Synthesis, characterization and biological study of some new metal-azo chelate complexes. J. Chem. Pharm. Res., 2016, 8(8): 296-302.

[19] A.A. Saeyda, Synthesis and characterization of some metal complexes derived from azo compound of 4 , 4'-methylenedianiline and antipyrine: Evaluation of their biological activity on some land snail species. Journal of Molecular Structure, 2015, 1099: 567-578.

[20] S. Suhad, Synthesis and spectral studies of heterocyclic azo dye complexes with Y (III) and La (III) ions. AlQadisiyah Journal of Pure Science, 2017, 19(1): 67-77.

[21] T. Giuseppe, Ligating properties of thionitrosoamines: I. Neutral mononuclear N-thionitrosodimethylaminepalladium (II) and-platinum (II) complexes. Journal of Organometallic Chemistry, 1983, 252(3): 381-387.

[22] B. Anupamp, C. Kumari Gyana, Cobalt (II) complexes of ONO donor Schiff bases and N,N donor ligands: Synthesis, characterization, antimicrobial and DNA binding study. International Journal of Research in Chemistry and Environment, 2013, 3(2): 172-180.

[23] P.A.L. Sanjib, Synthesis, spectral and electrochemical properties of 1-alkyl-2-(naphthyl- $\beta$-azo) imidazole complexes of platinum (II) and the reaction with pyridine bases. Single-crystal X-ray structure of dichloro-[1-ethyl- 
2-(naphthyl- $\beta$-azo) imidazole] platinum (II). Polyhedron, 2000, 19(10): 1263-1270.

[24] M. Kurtoğlu, M. Baydemir, and S. Ayşe, Studies on mononuclear transition metal chelates derived from a novel (E, E)-dioxime: Synthesis, characterization and biological activity. Journal of Coordination Chemistry, 2007, 60(6): 655-665.

[25] K. Nakamoto, Infrared and Raman spectra of inorganic and coordination compounds, 6th ed. John Wiley \& Sons,
Inc., 2009: 131-142.

Copyright $(\subset$ Faez Abdul-hussein Alrammahi. This is an openaccess article distributed under the terms of the Creative Commons Attribution License, which permits unrestricted use, distribution, and reproduction in any medium, provided the original author and source are credited. 